No. 2(71), 2021, pp.171-182

https://doi.org/10.12797/Politeja.18.2021.71.09

\author{
Mykola POLOVYI (D) \\ Vasyl' Stus Donetsk National University \\ 1@myko.name
}

\title{
EXPLOITATION OF THE RIGHT \\ TO FREEDOM OF EXPRESSION \\ FOR PROMOTING PRO-RUSSIAN \\ PROPAGANDA IN HYBRID WAR
}

ABSTRACT The paper is devoted to the process and results of an analysis of abusing the right to freedom of expression for promoting pro-Russian propaganda in hybrid war against Ukraine at the present stage. It is shown that due to the peculiarities of the political situation in modern Ukraine, pro-Russian propaganda is most common in social networks. The study is conducted on the data from a weekly monitoring of pro-Russian propaganda in the Facebook public groups ('publics') of the Odessa region of Ukraine. Effective typology of propaganda messages in social networks is created and described. Its connection with the Lasswell's test is grounded. General characteristics of pro-Russian propaganda promotion under the guise of implementing the right to freedom of expression in the Facebook publics of the Odessa region in the first quarter of 2021 are described. It has been found that the common tone of contemporary pro-Russian propaganda in Ukraine is becoming increasingly 'soft'. The main group of contemporary proRussian propaganda messages are about the 'shared past' of Ukraine and Russia during the Soviet era, shared nostalgia for the 'brave past world.' 'Soft' promotion of the Russian information agenda and indicating Russian or Ukrainian pro-Russian media as a familiar source of information is the second huge group of propaganda texts. It is noted that both most popular 'patterns' of the propaganda can be considered propaganda only in the context of Russia's undeclared war against Ukraine.

Keywords: right to freedom of expression, pro-Russian propaganda, hybrid war, monitoring of social networks, Facebook, Ukraine 


\section{INTRODUCTION}

Results of several media monitorings of 2019-2021 in which the author participat$\mathrm{ed}^{1}$ and their comparison with the situation in 2014-2015 enable us to say that over the past seven years, pro-Russian propaganda in Ukraine during the hybrid RussianUkrainian war evolved from overt in 2014 to more covert, more sophisticated in 2020. Barefaced fakes of 2014 are replaced by more subtle messages that contain half-truths or not-all-truths. For example, the well-known fake reports about 'Ukro-fascists' who 'crucify boys' were openly spread in some Ukrainian media and on all social networks in 2014-2015 only.

Various anti-fake projects ${ }^{2}$ and the general increase in the level of media literacy of the population of Ukraine have made it extremely difficult to use glaring fake information in the media. In addition, since 2021, the Ukrainian government and law enforcement agencies have become more active in closing down blatantly propagandist media channels. ${ }^{3}$ As a result, modern pro-Russian propaganda, firstly, is mostly disguised under the right to express one's opinion and, secondly, is increasingly flowing into social networks.

Results of the monitoring of regional media, social networks to assess the quality and impartiality of local media coverage of elections and to identify misinformation,

“Описовий звіт за січень 2021 року - Полтавська область”, IDPO.ORG.UA Iнститут демократії ім. Пилипа Орлика, at <https://idpo.org.ua/reports/4028-opisovij-zvit-za-sichen-2021-roku-poltavskaoblast.html>, 19 February 2021; “Описовий звіт за жовтень 2020 року - Харківська область”, IDPO.ORG.UA Iнститут демократії ім. Пилипа Орлика, at <https://idpo.org.ua/reports/3879opisovij-zvit-za-zhovten-2020-roku-xarkivska-oblast.html>, 04 November 2020; "Описовий звіт за травень 2020 року - Харківська область”, IDPO.ORG.UA Iнститут демократії ім. Пилипа Орлика, at <https://idpo.org.ua/reports/3550-opisovij-zvit-za-traven-2020-roku-xarkivska-oblast. html>, 15 June 2020; “Моніторинговий звіт за січень-лютий 2020 року - Харківська область", IDPO.ORG.UA Iнститут демократії ім. Пилипа Орлика, at <https://idpo.org.ua/reports/3308monitoringovij-zvit-za-sichen-lyutij-2020-roku-xarkivska-oblast.html>, 02 March 2020; "Херсонська область - моніторинговий звіт за квітень 2019 року”, IDPO.ORG.UA Iнститут демократії iм. Пилипа Орлика, at <https://idpo.org.ua/reports/2726-xersonska-oblast-monitoringovijzvit-za-kviten-2019-roku.html>, 18 Мау 2019; “Моніторинговий звіт за червень 2019 року Миколаївська область", IDPO.ORG.UA Інститут демократії ім. Пилипа Орлика, at <https://idpo. org.ua/reports/2880-monitoringovij-zvit-za-cherven-2019-roku-mikola\%D1\%97v.html>, 29 July 2019; “Моніторинг регіональних медіа піА час виборів 2020 (проміжний звіт)", Одеська обласна організація Комітету вибориів України, аt <http://cvu.od.ua/ua/library/monitoring-regionalnihmedia-pid-chas-viboriv-2020-promijniy-zvit_1232/>, 20 October 2020; “Моніторинг регіональних медіа під час виборів 2020 (звіт)”, Одеська обласна організація Комітету вибориів України, ат <http://cvu.od.ua/ua/library/monitoring-regionalnih-media-pid-chas-viboriv-2020-zvit_1269/>, 10 December 2020.

2 "StopFake", StopFake.org, at <https://www.stopfake.org/>; "About the International Fact-Checking Network", Poynter, at <https://www.poynter.org/about-the-international-fact-checking-network/>, 08 September 2017.

3 “БАокування каналів «112 Україна», ZIK i NewsOne y YouTube. Мінкульт готує звернення до аАміністрації відеохостингу”, ITC.ua, at <https://itc.ua/news/blokuvannya-kanaliv-112-ukra\%D1\%97na-zik-i-newsone-u-youtube-minkult-gotu\%D 1\%94-zvernennya-do-administaczi\%D1\%97-videohostingu/>, 03 February 2021. 
covert attempts to manipulate public opinion ${ }^{4}$ showed that most of the propaganda in Ukraine is spread through Facebook communities and Telegram channels.

The aim of the paper is to analyze how the right to freedom of expression is exploited for promoting pro-Russian propaganda in the hybrid war against Ukraine at the present stage. The study was conducted on the materials of Facebook publics of the Odessa region of Ukraine. As it is known, this region is a part of the so-called Novorossia: the territory of eight southern and eastern regions of Ukraine, which according to Russian experts and authorities, potentially aspire to join Russia.

It should be noted that this study does not address the issue of primary sources and motives for posting pro-Russian propaganda posts: that is, they can really be sincere expressions of personal opinion, or can be inspired or even carried out by proRussian bots, and so on. The legal qualification of the content of certain messages also goes beyond the scope of this study. We are interested in the 'result': if a certain message corresponds to the purpose of pro-Russian propaganda, it belongs to the propaganda 'per consequentias.' Using the methodology described below, we can assess the distribution of such messages, their audience, and the potential impact on this audience.

\section{METHODS AND SOURCES}

The study is based on the data of weekly monitoring of pro-Russian propaganda in the Facebook public groups of the Odessa region, reaching more than 5 million readers, conducted by the author since February 2021..$^{5}$

The total sample of Facebook publics selected for monitoring is 185 pages. Media map includes:

- 87 pages (up to 100,000 subscribers) covering the news of the city of Odessa and Odessa region, but not belonging to the media;

- 43 pages of mass media;

- 21 pages of political parties;

- 21 pages of publics from previous categories but have temporarily stopped distributing posts;

\footnotetext{
“Моніторинг регіональних медіа під час виборів 2020 (звіт)”, Одеська обласна організація Комітету вибориів України, аt <http://cvu.od.ua/ua/library/monitoring-regionalnih-media-pidchas-viboriv-2020-zvit_1269/>, 10 December 2020.

5 "Ностальгія за СРСР та мова ворожнечі: результати тижневого моніторингу одеських соцмереж”, Ізбірком, at <https://izbirkom.org.ua/publications/medialiteracy/2021/tizhnevij-monitoring-fb-pablikiv-odeskoyi-oblasti-na-predmet-prisutnosti-prorosijskoyi-propagandi/>, 04 February 2021; “Моніторинг одеських соцмереж: «кінець епохи демократії та пропаганда”, Ізбірком, at <https://izbirkom.org.ua/publications/medialiteracy/2021/rezultati-tizhnevogo-monitoringu-odeskih-socmerezh-kinec-epohi-demokratiyi-ta-propaganda/>, 27 February 2021; “Моніторинг одеських соцмереж: туга за минулим з присмаком російських Ажерел”, Ізбірком, at <https://izbirkom.org.ua/publications/medialiteracy/2021/monitoring-odeskih-socmerezh-tuga-za-minulim-z-prismakom-rosijskih-dzherel/>, 1 May 2021.
} 
- 13 mass publics that cover the news of Odesa region, but are not mass media (100,000-500,000 subscribers).

The total number of subscribers to the selected pages as of the end of April 2021 is 5,435,921 participants.

All posts in these publics were analyzed on a week-to-week basis. The actual collection of posts was carried out using the Crowd Tangle service, a Facebook-owned tool that tracks interactions on public content from Facebook pages and groups, verified profiles, Instagram accounts, and subreddits. ${ }^{6}$

Further analysis was performed using several software modules in Python developed by the author. As part of the analysis, a dictionary search was performed to identify propaganda messages in accordance with the typology described below. Propaganda posts belonging to different types were identified, and a scale of interaction with them was assessed. These data were compared to the total number of posts and to the characteristics of interaction with all posts of every week.

The percentage of posts that contain propaganda but can be formally classified as usual expression of opinion within the implementation of the right to express an opinion was determined.

The formal typology of materials was also determined for all posts containing propaganda. The following types of posts were distinguished:

- photographs, which are usually captioned with 1-3 sentences (for example, "Odessa. Railway station. 1976", or "Students go to music school", 1971);

- text messages of more than three sentences with photo illustrations;

- videos, which are usually captioned with 1-3 sentences;

- text messages of more than 3 sentences, supported by video.

The number of channels (publics) that distributed messages displaying signs of propaganda was determined. During the monitoring period, their number ranged from 25 to 44 among a total of 185 publics. Crowd Tangle also determined the total audience of these pages. This number ranged from 1.5 to 1.7 million subscribers. The maximum possible number of 'active readers' of posts containing propaganda was also determined. This was done on the basis of the total amount of likes, reposts, and comments. In different weeks, this number ranged from 60,000 to 130,000 people. Let's note that the number of 'active readers' of propaganda messages amounted to 5-9\% of the total audience of publics that posted propaganda materials.

\section{TYPOLOGY OF PROPAGANDA MESSAGES AND FEATURES OF OPINION EXPRESSION IN SOCIAL NETWORKS}

The peculiarities of the use of propaganda in various media have been studied since the 1920s. A certain generalization of the ideas of the time about the means of propaganda

CrowdTangle Team (2021). CrowdTangle. Facebook, Menlo Park, California, United States, at $<$ https://apps.crowdtangle.com/>. 
were made by Harold D. Lasswell in his 1927 book Propaganda Technique in the World War. ${ }^{7}$ He later developed a method of detecting propaganda in the media, called the 'Lasswell tests' and found its application in the United States during World War II.

According to this methodology, in order to determine whether a media is propagandist, the presence and proportion of publications that should meet one or more of the following criteria were checked:

1) direct recognition: the obvious identification of the publication with the enemy;

2) parallelism: the coincidence of the content of the studied material with the content of hostile information resources;

3) coherence: compliance of the flow of materials with the declared goals of the hostile propaganda;

4) presentation: a balance of negative and positive attitudes towards the symbols of both warring parties;

5) source: the predominance of one source of information for an entire issue or several issues of the media;

6) hidden source: frequent publication of information materials without reference to the source;

7) originality: the use of words and phrases that are characteristic of the propaganda of the enemy;

8) distortion: distortion of various statements on general and/or specific topics in a way that is beneficial to one (enemy) side or corresponds to the position of the enemy side.

It is clear that eighty years after the invention, Laswell's tests cannot be used verbatim even for the analysis of conventional media and are even less suitable in the case of social networks, but it should be noted that some statements of Laswell's tests deserve attention, especially nos. 3, 7 and 8 , the presence of which is still an important criterion for fixing propaganda.

Let's make a note of some properties of social networks that are important in terms of identifying the use of the right to freedom of expression for propaganda:

- in the absence of a legal framework, it is currently difficult to imagine a lawsuit against any conventional media for disseminating propaganda, which would be compiled on the basis of any list similar to Lasswell's test;

- due to the peculiarities of social platforms such as Facebook or Telegram, even in the presence of relevant legislation on the media, it would be difficult to equate Facebook and Telegram communities to the media and, accordingly, to terminate their activities by court decision;

- at the same time, there are much wider (compared to 80 years ago and even 20 years ago) opportunities to spread propaganda messages on social networks. We point to this well-known fact only to note that the possibility of instant reposts in different publics makes the process of counteracting individual propaganda publics slow and ungrateful, and, on the other hand, makes it possible to quickly 
identify the entire network of publics involved in propaganda. Practice shows that due to the high speed of reposting, they are much faster than preparing new propaganda messages. This leads to the appearance of the same messages in seemingly different publics. When we add to this similarity the simultaneous appearance or 'support of likes' by the same users (more likely, bots), the detection of a propaganda network becomes a purely technical issue. In addition, unlike propaganda in the media of the second world war, propaganda texts on social networks are much shorter, which limits the possibility to hide the actual propaganda content and, at the same time, simplifies the detection of this content even by software.

Based on the abovementioned and on the results of previous media monitoring conducted in 2019 and $2020,{ }^{8}$ I identified a slightly different list of signs of propaganda on social networks, which is promoted under the guise of expressing one's own opinion. It seems that today the most informative features of contemporary propaganda in posts in the public FB and Telegrams are the following elements contained in the texts alone or in certain combinations:

1. Signs of intolerance, xenophobia, discrimination, intolerance to the Ukrainian people or to the representatives of the Ukrainian people. Applying offensive labels and hate speech to them. The presence in the text of a conscious treatment of Ukrainian nationality, the Ukrainian language as inferior, second-rate, incompetent. For example, the use of the words 'Sprechenführer,' 'doctor of death,' or the use of the word 'murderer,' 'criminal' in reference to certain Ukrainian politicians or activists.

2. Discrediting Ukrainian statehood at the stylistic level of the language and/or recognition/promotion of concepts directed against the Ukrainian state, attributes and symbols of its independence. The examples include such assertions as 'non-state,' 'state committing genocide of its own people, 'state ruled by Soros through his protégés,' 'external management [of the state], 'fascist state,' 'Bandera-Nazi henchmen.'

3. Misinformation, distortion of facts, texts with unreliable references to any controversial topics (including 'genocide in Ukraine, 'persecution' of national minorities; intolerance of residents of Western Ukraine; substandard behavior of Ukrainian soldiers; statements of some European officials and/or publications of some Western media on the language situation in Ukraine, the 'need' to 'give water' to Crimea, the 'need' to negotiate directly with the DLNR, etc.; Ukrainian politicians 'sold' to Western institutions (NATO, IMF, etc.) or individuals, such as Soros; any other 'hot news' (for instance Ukrainian/Western footprint "in the events of peace riots in Belarus"). Panicky texts, for example, 'currency panic,' 'Ukraine is facing a famine due to the coronavirus', 'impoverishment due to rising gas prices', etc.

To this category belongs the biased selection of news with a predominance of negative characteristics of Ukraine and/or Ukrainians, and/or certain phenomena/events in Ukraine or with Ukrainians; with the predominance of positive characteristics of the

For instance, “Моніторинг регіональних медіа під час виборів 2020 (звіт)”, Одеська обласна організація Комітету вибориів України, аt <http://cvu.od.ua/ua/library/monitoring-regionalnihmedia-pid-chas-viboriv-2020-zvit_1269/>, 10 December 2020. 
Russian Federation, and/or its official or unofficial representatives/goods/services, etc. For example, texts about the Ukrainian military only with negative information (committed a crime, took part in a road accident, etc.)

4. Messages with links to Russian information resources (not only in domain .ru, but with Russian-roots domain registration or hosting as strana.ua) and sources or resources that are the places for Russian propaganda promotion (resources, which in the past recorded an abnormal frequency of propaganda messages).

5. The presence of nostalgia for the times of the USSR and the Russian Empire. Allegations of the unity of the Ukrainian and Russian peoples, etc. Presentation of Russian news as domestic news. Use of old, non-decommunized names of streets and settlements in Ukraine without clarification that the places have new names now.

6. Support for separatism and tendencies towards territorial separation or fixation of territorial separation. For instance, messages about Odesa region with its supposedly separate 'Odesa nationality.'

7. Recognition of 'Luhansk democratic republic' (LNR) and 'Donetsk democratic republic' (DNR) and their independence and separateness (including statements such as 'there are no Russian troops in Donbass', the use of 'DLNR,' its 'institutions', politicians without quotes; using expressions such as 'government troops' (concerning the Armed Forces), 'in Donbass' (as if in the independent state). Recognition of the rights of the Russian Federation to the Crimea.

\section{GENERAL FEATURES OF PRO-RUSSIAN PROPAGANDA PROMOTION UNDER THE GUISE OF IMPLEMENTING THE RIGHT TO FREEDOM OF EXPRESSION IN THE FACEBOOK PUBLICS}

The total number of all posts of Odessa Facebook publics during the week ranged from 15,200 at the beginning of the monitoring period to 13,800 at the end of April 2021.

The share of propaganda materials was stable during the period and amounted to $1.7-3.4 \%$ of all posts.

Every week, at least $95 \%$ of propaganda materials can be formally attributed to posts that contain the usual expression of opinion within the right to freedom of expression.

Remarkable is a much larger number of interactions of the audience with propaganda materials compared to the interaction with materials that do not contain propaganda. The frequency of interaction with propaganda materials in all three types (likes, comments, and reposts) ranged from $7 \%$ to $15 \%$ of all interactions with all materials of the week. For example, in the last full week of April 2021, the following data were observed: an average of 35 reposts per propaganda post, while 10 regular reposts per regular post. One propaganda post receives approximately 224 likes and 25 comments. At the same time, a post without signs of propaganda has an average of 44 likes and 5 comments.

The total number of interactions with all posts in the public ranged from 800,000 to 1,000,000 likes, reposts, and comments. From 61,000 to 150,000 interactions out of this number were related to propaganda materials. 
In the last full week of April, posts containing propaganda were distributed via the following types of materials:

$42 \%$ - photographs and illustrations, captured with 1-3 sentences;

$35 \%$ - text messages of more than 3 sentences with photo illustrations;

$13 \%$ - videos, captured with 1-3 sentences;

$10 \%$ - text messages of more than 3 sentences, supported by video.

A similar proportion was observed throughout the monitoring. Therefore, it can be stated that photographs with short captions are the most popular means in which propaganda is 'mounted.' Please note that videos and photos with short captions make up more than $50 \%$ of all propaganda materials. Given that these photos and videos are usually in the public domain and have been previously published (like, for example, photos of Soviet-era cities or excerpts from Soviet feature movies), it is not difficult for the authors of the messages to claim their right to 'share pleasant memories.'

The main group of contemporary pro-Russian propaganda messages are about the 'shared past' of Ukraine and Russia during the Soviet era, shared nostalgia (from 'the world's most delicious ice cream for 5 kopeeks' to cartoons, movies, actors, etc.) and the convenience of common language of daily communication (naturally, Russian, according to the propaganda). Messages belonging to this type of propaganda make up at least $60 \%$, and sometimes up to $75 \%$ of all propaganda materials. Interestingly, it is posts of this type that receive the most numerous likes (sometimes more than $90 \%$ of all propaganda materials likes), comments, and reposts (also up to 70-80\%). This phenomenon creates two problems: it is almost impossible to catch a propagandist 'red-handed' because the 'saturation' of the actual propaganda message is very low and, worst of all, the subscribers of these publics perform part of the job of putting propaganda in their heads: by participating (reading and commenting) in 'the light proRussian public group' they support further light dissipation of almost homeopathic doses of propaganda. A perfect example of this approach is a post related to nostalgia for the USSR: neat photo of a Soviet era hometown with an appropriately nostalgic comment.

The second most frequent mean of propaganda is a 'soft' promotion of the Russian agenda and the Russian or Ukrainian pro-Russian media as familiar sources of information. Frankly speaking, both most popular 'patterns' of propaganda can be considered propaganda only in the context of Russia's undeclared war against Ukraine. Under normal, peaceful conditions, it would be impossible to see these posts as propaganda.

Let us clarify the following dual attitude to propaganda posts: as the practice of the capture of Crimea by the Russian Federation and its capture of de facto control over parts of Luhansk and Donetsk regions in 2014 showed, not only armed supporters of the Russian Federation but also indulgent attitude of the vast - passive - majority of the population to these events played an important role. This attitude was achieved by the Russian occupiers precisely because of the pre-rooted idea of a single past,' of the 'good times' of this 'single past of two nations,' of the 'unity of the Russian and Ukrainian peoples,' including linguistic unity, etc. Thus, in the context of the war, all messages that demonstrate and reproduce relevant ideas about the 'unity' 
of languages, space, past, etc., are part of the propaganda, regardless of the intentions and degree of personal sincerity of their senders.

Another feature of propaganda under the guise of expressing personal opinion is that the general field of propaganda in the South of Ukraine is fueled at a subliminal level by the 'habit of Russian-speaking' in a large part of the population. This allows pro-Russian forces to easily 'pack' propaganda content into a Russian-language wrapper.

\section{CONCLUSION}

The common tone of contemporary pro-Russian propaganda in Ukraine is becoming increasingly 'soft.' It draws more and more from an exploitation of the right to freedom of expression. More than $90 \%$ of all propaganda - disguised as nostalgic materials or as texts that accustom readers with the Russian information space - hides behind this right.

A well-known attribute of social networks to create comfortable, unchallenging information bubbles' for users in which they feel in a familiar, pleasant environment creates an impression of a certain unanimity in views on the world and life, which is gradually reinforced by reading posts and comments 'attuned' to this public group, and their own comments. All such texts are sent based on the right to express one's own opinion. Additional 'internal' memes and material stamps are gradually produced in such 'information bubbles.' Not every meme of this kind gets Internet-famous, but within a group of subscribers, long communication or just reading the public accustoms the reader to certain mental patterns and views. Thus, as a result, it is possible to achieve the goal of propaganda through infrequent feeding of truly propagandist messages. Instead, these posts may display a rather mild form of propaganda or even seem outwardly neutral, but the subscribers of the group can take such posts in the sense intended by the propagandist. There are no possibilities to oppose such propaganda on legal grounds.

It should be borne in mind that in a potentially interesting region for the Russian Federation, which is the Odessa region, currently about $1,000,000$ people are affected by the influence of Facebook publics which spread propaganda and about 150,000 of them actively respond to pro-Russian propaganda messages with likes, reposts, or comments.

For several reasons, the Ukrainian state hardly takes on the fight against publics on social networks that distribute propaganda content, so citizens have few options:

1) not to worry and consume the information of their usual publics;

2) to be informed about which publics are involved in the simultaneous placement of propaganda and, accordingly,

2.1) deliberately expose oneself to the danger of being periodically influenced by propaganda,

2.2) knowingly avoid viewing and subscribing to publics that have been spotted in the 'propaganda network' - among the publics that published propaganda posts. 


\section{BIBLIOGRAPHY}

"About the International Fact-Checking Network", Poynter, at <https://www.poynter.org/ about-the-international-fact-checking-network/>.

"Blokuvannâ kanaliv «112 Ukraïna», ZIK i NewsOne u YouTube. Minkul't gotue zvernennâ do administraciï videohostingu", ITC.ua, at <https://itc.ua/news/blokuvannya-kanaliv112-ukraïna-zik-i-newsone-u-youtube-minkult-gotue-zvernennya-do-administacziïvideohostingu/ $>$.

CrowdTangle Team (2021). CrowdTangle. Facebook, Menlo Park, California, United States, at $<$ https://apps.crowdtangle.com/>.

"Hersons'ka oblast' - monitoringovij zvit za kviten' 2019 roku”, IDPO.ORG.UA Institut demokratiï im. Pilipa Orlika, at <https://idpo.org.ua/reports/2726-xersonska-oblast-monitoringovij-zvit-za-kviten-2019-roku.html>.

Lasswell H.D., Propaganda Technique in the World War, New York 1938, at <https://babel. hathitrust.org/cgi/pt?id=mdp.39015000379902>.

"Monitoring odes'kih socmerež: "kinec' epohi demokratiii" ta propaganda", Izbirkom, at <https://izbirkom.org.ua/publications/medialiteracy/2021/rezultati-tizhnevogo-monitoringu-odeskih-socmerezh-kinec-epohi-demokratiyi-ta-propaganda/ > .

"Monitoring odes'kih socmerež: tuga za minulim z prismakom rosijs'kih džerel", Izbirkom, at $<$ https://izbirkom.org.ua/publications/medialiteracy/2021/monitoring-odeskih-socmerezhtuga-za-minulim-z-prismakom-rosijskih-dzherel/>.

"Monitoring regional'nih media pid čas viboriv 2020 (promižnij zvit)", Odes'ka oblasna organizaciâ Komitetu viborciv Ukraïni, at <http://cvu.od.ua/ua/library/monitoringregionalnih-media-pid-chas-viboriv-2020-promijniy-zvit_1232/>.

“Monitoring regional'nih media pid čas viboriv 2020 (zvit)", Odes'ka oblasna organizaciâ Komitetu viborciv Ukraïni, at <http://cvu.od.ua/ua/library/monitoring-regionalnihmedia-pid-chas-viboriv-2020-zvit_1269/>.

“Monitoringovij zvit za červen' 2019 roku - Mikolaïv'ka oblast", IDPO.ORG.UA Institut demokratiï im. Pilipa Orlika, at <https://idpo.org.ua/reports/2880-monitoringovij-zvit-zacherven-2019-roku-mikolaiv.html $>$.

"Monitoringovij zvit za sičen'-lûtij 2020 roku - Harkivs'ka oblast", IDPO.ORG.UA Institut demokratii im. Pilipa Orlika, at <https://idpo.org.ua/reports/3308-monitoringovij-zvit-zasichen-lyutij-2020-roku-xarkivska-oblast.html>.

"Nostal'giâ za SRSR ta mova vorožneči: rezul'tati tižnevogo monitoringu odes'kih socmerež", Izbirkom, at <https://izbirkom.org.ua/publications/medialiteracy/2021/tizhnevij-monitoring-fb-pablikiv-odeskoyi-oblasti-na-predmet-prisutnosti-prorosijskoyi-propagandi/> .

“Opisovij zvit za sičen' 2021 roku - Poltavs'ka oblast", IDPO.ORG.UA Institut demokratii im. Pilipa Orlika, at <https://idpo.org.ua/reports/4028-opisovij-zvit-za-sichen-2021-rokupoltavska-oblast.html>.

“Opisovij zvit za traven' 2020 roku - Harkivs'ka oblast", IDPO.ORG.UA Institut demokratii im. Pilipa Orlika, at <https://idpo.org.ua/reports/3550-opisovij-zvit-za-traven-2020-rokuxarkivska-oblast.html>. 
“Opisovij zvit za žovten' 2020 roku - Harkivs'ka oblast”, IDPO.ORG.UA Institut demokratii im. Pilipa Orlika, at <https://idpo.org.ua/reports/3879-opisovij-zvit-za-zhovten-2020-rokuxarkivska-oblast.html>.

"StopFake", StopFake.org, at <https://www.stopfake.org/>.

“БАокування каналів «112 Україна», ZIK i NewsOne y YouTube. Мінкульт готує звернення до адміністрації відеохостингу”, ITC.ua, at <https://itc.ua/news/blokuvannya-kanaliv112-ukra\%D1\%97na-zik-i-newsone-u-youtube-minkult-gotu\%D1\%94-zvernennya-doadministaczi\%D1\%97-videohostingu/>.

“Моніторинг одеських соцмереж: «кінець епохи демократії» та пропаганда”, Ізбірком, at $<$ https://izbirkom.org.ua/publications/medialiteracy/2021/rezultati-tizhnevogo-monitoringu-odeskih-socmerezh-kinec-epohi-demokratiyi-ta-propaganda/>.

“Моніторинг одеських соцмереж: туга за минулим з присмаком російських Ажерел”, Ізбірком, at <https://izbirkom.org.ua/publications/medialiteracy/2021/monitoringodeskih-socmerezh-tuga-za-minulim-z-prismakom-rosijskih-dzherel/>.

“Моніторинг регіональних медіа піА час виборів 2020 (звіт)”, Одеська обласна організація Комітету вибориів України, аt <http://cvu.od.ua/ua/library/monitoring-regionalnihmedia-pid-chas-viboriv-2020-zvit_1269/>.

“Моніторинг регіональних медіа піА час виборів 2020 (проміжний звіт)”, Одеська обласна організація Комітету вибориів України, аt <http://cvu.od.ua/ua/library/ monitoring-regionalnih-media-pid-chas-viboriv-2020-promijniy-zvit_1232/>.

“Моніторинговий звіт за січень-лютий 2020 року - Харківська область”, IDPO.ORG.UA Iнститут демократї ім. Пилипа Орлика, at <https://idpo.org.ua/reports/3308-monitoringovij-zvit-za-sichen-lyutij-2020-roku-xarkivska-oblast.html>.

“Моніторинговий звіт за червень 2019 року - Миколаївська область”, IDPO.ORG.UA Iнститут демократії ім. Пилипа Орлика, at <https://idpo.org.ua/reports/2880-monitoringovij-zvit-za-cherven-2019-roku-mikola\%D1\%97v.html>.

“Ностальгія за СРСР та мова ворожнечі: результати тижневого моніторингу одеських соцмереж”, Ізбірком, at <https://izbirkom.org.ua/publications/medialiteracy/2021/tizhnevij-monitoring-fb-pablikiv-odeskoyi-oblasti-na-predmet-prisutnosti-prorosijskoyi-propagandi/>.

“Описовий звіт за жовтень 2020 року - Харківська область”, IDPO.ORG.UA Iнституm демократії ім. Пилипа Орлика, at <https://idpo.org.ua/reports/3879-opisovij-zvit-zazhovten-2020-roku-xarkivska-oblast.html>.

“Описовий звіт за січень 2021 року - Полтавська область”, IDPO.ORG.UA Iнституm демократії ім. Пилипа Орлика, at <https://idpo.org.ua/reports/4028-opisovij-zvit-za-sichen-2021-roku-poltavska-oblast.html>.

“Описовий звіт за травень 2020 року - Харківська обкасть”, IDPO.ORG.UA Iнституm демократії ім. Пилипа Орлика, at <https://idpo.org.ua/reports/3550-opisovij-zvit-zatraven-2020-roku-xarkivska-oblast.html>.

“Херсонська область - моніторинговий звіт за квітень 2019 року”, IDPO.ORG.UA Iнститут демократї̈ ім. Пилипа Орлика, at <https://idpo.org.ua/reports/2726-xersonska-oblast-monitoringovij-zvit-za-kviten-2019-roku.html>. 
Mykola POLOVYI PhD in History (1997), D.Sc. in Political Science (2011). Professor at the Department of Political Science and Public Administration at the Vasyl' Stus Donetsk National University, Vinnitsa, Ukraine. His research interests include quantification and modeling in history and the theory of history, simulations and forecasting of social and political processes on the base of the synergetic approach. Author of two monographs: Prognostication of the Paradigm Shift of Historical Cognition: Searching for a Method (2010, in Russian) and Political Processes: Theory and Practice of Simulation (2011, in Ukrainian). An editor-in-chief of several academic journals: international Evropský politický a právni diskurz (European Political and Law Discourse) and Ukrainian Bulleting of Vasyl' Stus Donetsk National University. Political Science Series. Personal web-site: http://myko.name. Profile at WoS: https://publons.com/ researcher/1632603/mykola-polovyi/. 